\title{
XXXII. On the Gopher-wood of the received version of the scriptures
}

\author{
W.G. Carter Esq.
}

To cite this article: W.G. Carter Esq. (1834) XXXII. On the Gopher-wood of the received version of the scriptures, Philosophical Magazine Series 3, 4:21, 178-182, DOI:

$10.1080 / 14786443408648299$

To link to this article: http://dx.doi.org/10.1080/14786443408648299

册 Published online: 01 Jun 2009.

Submit your article to this journal $₫$

Џ Article views: 3

Q View related articles $\square$ 
or perhaps more particularly of Lower Egypt, the place of its residence and ravages.

It is, however, necessary to observe that the insect to which modern entomologists have given the name of CEstrus, is totally different from the fty which Aristotle distinguished by that name. The modern OEstrus shuns the water, it is no bloodsucker, has no proboscis, and scarcely any mouth, and in flying makes no noise; while the $\boldsymbol{E}$ Estrus of the Greeks possesses many of the specific characters and habits which Bruce ascribes to the zimb.

These considerations are submitted to the attention of naturalists with hesitation and doubt. But having had the good fortune of directing the studies of one of the gentlemen whom the Pacha of Egypt has sent to this country to be educated, the writer hopes soon by his means to obtain specimens which will enable naturalists to clear up this interesting and doubtful point.

XXXII. On the Gopher-wood of the received Version of the Scriptures. By W. G. Carter, Esq.

To the Editors of the Philosophical Magazine and Journal. Gentlemen,

IN a letter from Mr. Beke in your Number for August last, on a paper by Mr. Drummond Hay on certain Plants of Marocco, and the Cedar of the Ancients, it is said that the word 7 (Gopher), used to express the wood of which the Ark of Noah was built, is probably the same as ذפר Kopher means pitch, and that the tree in question would therefore appear to be a pitch tree.

This change has, I believe, never been before suggested, but the change of letters of the same organ is common in Hebrew as in other tongues. That it has been made in the particular instance seems highly probable, and the correction very admissible. Admitting, then, that Gopher is identical with Kopher, I still think it is very questionable that Kopher means pitch, and atzei Kopher, pitch trees, for the following considerations.

'Though the word is of very frequent use in the Hebrew Scriptures in the sense of cover over, atone for, expiate, and is the word constantly employed, particularly in the Pentateuch, to express that meaning, not one passage, I believe, can be found in which it has the former import. The nearest to it, and the only one I can find having the like sense, is Isaiah xxviii. 18. "Your covenant with death shall be disannulled:" and there we need not infer the meaning of can- 
celled by daubing with pitch, but that of covered from sight, put away, not allowed to be enforced.

The pitch obtained from wood could scarcely have been known at that early age, in a country where, probably, as now, whole pools of it existed, and it flowed spontaneously from the earth, and when boats and ships (for which is its more important use) could be very little known.

Two other words are furnished by the language to express the various kinds of pitch or bitumen then employed, the more general term hemer signifying, among other things, red earth, soil, or cement (from ${ }^{2} \prod_{\text {T }}$, chamar or hamar, to redden), and Iְפָ (zepheth). Sulphur was expressed by The two latter words occur in Isaiah xxxiv. 9., and sulphur and pitch or bitumen, are clearly, as expressed, severally intended; "The streams shall be turned into pitch, the dust into brimstone." Dense fumes charged with sulphur are sent forth during volcanic eruptions, and it is found in abundance in volcanic deposits. The elder Pliny was killed by such fumes. Hemer is in a few passages employed to signify some other tenacious soil or cement. Moses's ark of bulrushes was covered with both hemer and zepheth; but it was also used to express bitumen. The pits in the vale of Siddim (now the Dead Sea), into which the King of Sodom and others fell, were of hemer, and pits of bitumen are still found there (Gen. xiv. 10). The same was used (xi. 3.) in building the Tower of Babel in the plain of Shinar to the east of Babylon, and bitumen is known to have been used in the buildings of $\mathrm{Ba}-$ bylon. (Dion. Cass. lib. 68.) The notion of red might be taken from the lighter petroleum, which is of a reddish brown, appearing on the surface.

The Hebrew word which expressed to atone, atonement, expiation, and also the mercy-seat of pure gold over which the Divine glory appeared, were forms of the same word Kopher. There is in Hebrew no paucity of terms having the like import of a covering; and that a word should have been selected for these great and revered objects, with the meaning of a sliming over of pitch, seems far from probable.

Trees that we know yield pitch are, moreover, very often referred to in the Hebrew Scriptures. Of fir, בר verowesh,

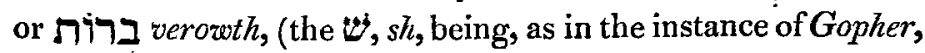
changed to another letter of the like organ, $\pi, t h$,) as well as cedar trees, a very large number were obtained for Solomon's Temple; and that verowsh was truly fir wood, appears highly probable from the use made of it. Solomon built the walls 
and the floor with cedar, in (erez), but covered the floor of the house with planks of fir (verowsh). 1 Kings vi. 15. We find fir wood the most suitable for musical instruments: verorosh also was so employed; "David and all the house of Israel played on all manner of fir wood (veroresh) instruments."

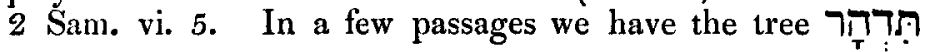
(tidhar). Isa. xli. 19. "I will set in the desert the fir tree (veroresh) and the pine (tidhar):" probably affording the etymon of the Latin teda, the heart of a pine, a torch.

The cedar, is often named in the Old Testament. It was eminently the tree of Lebanon. It was fragrant: " the smell of Lebanon," 4. Cantic. It was a noble lofty tree. Ez. xxxi. "A cedar in Lebanon, with fair branches and with a shadowing shroud, and of an high stature. The fir trees were not like his boughs, nor any tree in the garden of God was like unto him in his beauty.", When Maundrell visited Lebanon there were not many left, but enough to identify the tree. A few were of immense size. " There are some of them," says Mr. Buckingham (Travels), " ten or twelve feet diameter in the trunk, with branches of corresponding size, each like a large tree, extending outwards."

Then if it were neither the fir, the pine, nor the cedar, what was the Kopher tree? Dr. Hales considers it was the cypress. "Probably," says Taylor on this word in his Hebrew Concordance, " the cypress, a tree with a straight, smooth, long stem, and every way fit for building the ark." There are, however, two varieties of the Cupressus sempervirens, and one of them is a spreading tree. But that the cypress was the tree, can we at this remote period expect much better assurance than in the name having been continued from the Hebrews through the Greeks to the present time? Kopher, or koropher, (the $p$ and $p h$ being in Hebrew the same letter,)

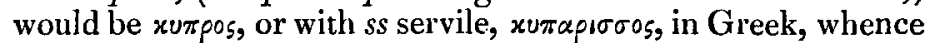
the Latin cupressus, and thence our 'cypress'. And the cypress tree was, as Taylor observes, every way fit for the purpose. The wood has a healthful odour, is extremely hard, yet elastic, it resists the worm, and is considered even superior to cedar. It is a tree of a warm climate, and is met with in China and many parts of Asia, and in the Levant. Thucydides (near 500 years B.C.) mentions (1. 2.) a public funeral at which the bones of the warriors were placed in

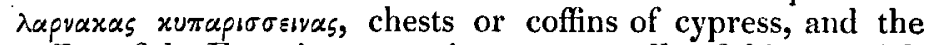
coffins of the Egyptian mummies are generally of this material. The cypress-wood doors of old St. Peter's at Rome, placed there by Constantine, were said to have shown no signs of 
decay when the brazen ones were substituted by Pope Eugenius IV., a period of 1100 years. Indeed its unequalled durability serves much to identify the tree, for the ark is considered to have been no less than 120 years in building, and if made of a more perishable material, one part would have decayed ere the other were completed.

The Kopher is thrice mentioned in the Canticles. In 7th chap. "Come my beloved, let us lodge in the villages" (bakipharim), "among the cypress trees" would be more in keeping with the context. In the 1 st and 4 th chap. where it is called 'camphire,' 'camphire spikenard,' ' a cluster of camphire,' the fragrant shrub and its precious oil mentioned by Pliny (lib. 12. cap. 24.) as cupros, and which grew in abundance in Egypt, Cyprus, Ascalon, \&c., are understood, and were doubtless intended. There seems to have been no very marked distinction of name between the tree and the shrub. Pliny is certainly treating of the tree in lib. 36 . cap. 33., though he refers to Cato De Re Rustica, who noticing the Cupressus, mentions the sowing and weeding of it, (cap. $48 \& 151$ ). The difficulty, perhaps, may be thus explained. The cypress probably grew in plantations to the common size of a branch, or was trained to shoot out small branches. These were used on funeral occasions, as well at the house entrance as in the procession, at the pile and at the tomb, and were so valuable that a fall of cypress, made once in thirteen years, sufficed for a daughter's portion (ibid.).

The same name having been given in both languages to the shrub, and the same or a similar name by the Greeks to the tree, favours the inference that for some reason common to both people, though not manifest to us, the like term was used in each language for the two productions.

I think it results from the foregoing remarks that we should be justified in reading the passage under consideration thus: "Make thee an ark of cypress wood (Kopher): thou shalt make rooms in the ark, and with cypress (Kopher) shalt thou cover it within and without." A Hebrew critic has lately proposed to render the latter Kopher 'atonement'. It will certainly bear at least as well the construction of ' covering' only, and would then be read (though I prefer the former reading), with a slight change of words, but with the same import, "thou shalt make it of cypress wood, and cover it, \&c., with a covering," $i$. $e$. " thou shalt thus completely or surely cover it ;" a mode of expression often occurring in the Hebrew Scriptures, as in Isaiah xxii. 17., where it is found in both parts of the

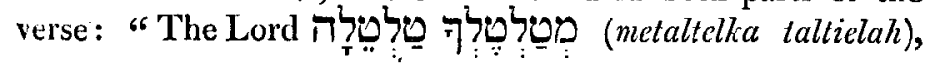


will carry thee captive into captivity," i.e. will surely carry thee captive, and הטעִ (we-oteka atah), "cover thee with a covering," i.e. surely, or completely, cover thee. And it may be noticed, that a particular command thus to cover the ark, seems to have been more needed than a command to daub it with pitch, for navigation in early society is usually performed in boats made of a single tree. It is after some progress in the art, that men begin to cover within and without with a covering of wood.

I have made the above observations, assenting to the opinion to which many would object, that a reference to the existing productions of the climate in which the ark was built, may not be irrelevant to such an inquiry, and believing it can be satisfactorily shown from the Mosaic history of the Deluge, that, in the opinion of its autbor, the upper strata of the earth have not undergone those great and universal changes which some attribute to the event, and that the present appearances of the earth's surface are in correspondence with the history.

Temple Chambers, Jan. 1834.

I am, Gentlemen, yours, \&c.

W. G. Canter.

XXXIII. Experimental Researches regarding certain Vibrations which take place between Metallic Masses having different Temperatures. By J AMES D. Forbes, Esq., F.R.SS.L. \& Ed. Professor of Natural Philosophy in the University of Edinburgh.

[Concluded from p. 28.]

\section{Influence of Figure upon the Vibrations.}

37. I HAVE already noticed the form of the apparatus which I have generally employed. The time of the oscillations and their magnitude depend upon the figure of the vibrating mass, which seems to act just as in the case of a pendulum, or rather of a rocking-stone, the impulse which it receives at each vibration appearing to be given at whatever instant of time the contact of the vibrating edges with the block is effected. This, however, must be understood within certain limits. There must be a decisive interval of time between the two contacts, for if the surface, instead of having two solid angles, as in the bar described above, merges into a continued curve, the vibrations will not take place. If, by any means, however, the period of contact of two portions of the curved surface with the block be prolonged, the impulse will be obtained; as in the case of a silver spoon, used as a bar, where the bowl of the spoon rests upon the block. No vibrations 